\title{
Pathogenesis and laboratory diagnosis of non-tuberculous urinary tract infection: $\mathrm{A}^{\text {review }}{ }^{1}$
}

\author{
W. BRUMFITT AND A. PERCIVAL \\ From the Department of Pathology, Edgware General Hospital, \\ Edgware, Middlesex, and the Wright-Fleming Institute, \\ St. Mary's Hospital, London
}

\section{PATHOGENESIS}

CHRONIC PYELONEPHRITIS Chronic pyelonephritis is the most common renal lesion found at necropsy. When rigid histological criteria are applied, the incidence of chronic pyelonephritis in consecutive routine hospital necropsies has been found to be between 3 and $9 \%$ (Gibson, 1928; Jackson, Dallenbach, and Kipnis, 1955; Brod, 1956; Kimmelstiel, Kim, Beres, and Wellmann, 1961).

Retrospective examination of hospital records shows that the lesion was unsuspected in a substantial proportion of these patients (Jackson et al., 1955). It is known that many patients suffering from chronic pyelonephritis do not give a history of previous urinary tract infection and the urine is frequently found to be free from infection. This has raised doubts in the minds of some workers about the relationship between acute urinary tract infection and chronic pyelonephritis, and Kimmelstiel et al. (1961) do not consider that the role of bacterial infection in chronic pyelonephritis is established. Although it is obviously impossible to implicate bacterial infection in every case evidence from two directions supports the view that renal infection is able to initiate a process which progresses to chronic pyelonephritis. First, follow-up studies on children who have had urinary tract infection have shown that an alarmingly high proportion died from chronic pyelonephritis (Woodruff and Everett, 1954; Macaulay and Sutton, 1957). Secondly, it is possible to induce acute pyelonephritis in a group of experimental animals and then study the progress of the lesion by killing the animals at subsequent intervals and examining their kidneys. In this way workers were able to demonstrate the progressive development of a renal lesion which satisfied the strictest criteria of chronic pyelonephritis (Heptinstall, Michaels, and Brumfitt. 1960).

${ }^{1}$ This review was part of a symposium on non-tuberculous urinary tract infections held at the Association of Clinical Pathologists' spring meeting at Bristol on 10 April 1964.
It seems possible, therefore, that bacteriah infection plays a part in the aetiology of all cases of pyelonephritis but infection may be associated with vascular or auto-immune processes in addition. Knowledge of the aetiology is of great importance ins attempts to prevent chronic pyelonephritis, for infection alone is the cause early detection and elimination of urinary tract infection will be effective? If bacterial infection initiates another pathologica process which is itself progressive then the effectiveso ness of antibacterial chemotherapy will be less.

Vascular lesions Kincaid-Smith (1955) suggested that much of the scarring seen in the chronic stages of pyelonephritis was the end result of a narrowing of the lumina of arteries of interlobular and arcuatên size which in turn was a consequence of the acuteD arteritis at the stage of acute infection. To study this theory further we induced acute pyelonephritis ing rabbits and observed progression towards chronic pyelonephritis by sacrificing animals at the appro priate intervals over a period of nine months (Heptinstall et al., 1960). Arteriography of the intact kidneys and subsequent histological examin ation showed that ischaemia caused by organie arterial narrowing played an insignificant parto Furthermore, Kimmelstiel (1960) studied human material from a large number of cases of acute pyelonephritis and was only once able to demon $\rightarrow$ strate an arteritis.

Auto-immune mechanisms An immunologica basis for chronic pyelonephritis has been suggested by the histological similarity to that seen in trans $N$ planted kidneys (Simonsen, Buemann, Gammeltoft Jensen, and Jørgensen 1953). This has led to the exame ination of sera for kidney antibodies from patients witk bacteriuria as well as from those with chronic pyelone phritis (Mackay and Larkin, 1958; Kramer, Watt $\stackrel{\text { क }}{+}$ Howe, and Parrish, 1961 ; Kalmanson and Guze, 1962,0 1963). So far the search for antibodies has been unrewarding, and, although these negative findings? do not finally exclude the role of immune mechanisms $\mathbb{D}$ at the present time there is no evidence to support 
the view that auto-immune mechanisms play a part in the genesis of chronic pyelonephritis.

Persistent infection It was suggested many years ago (Box, 1908) that infection may persist in a subclinical form and cause progressive destruction of renal tissue. By serotyping Esch. coli strains against the $\mathrm{O}$ antigen we have demonstrated that even though the patient is free from symptoms following an attack of acute pyelonephritis the organism may persist in the urine for many months. In other patients we have observed that the urine initially becomes sterile but subsequently asymptomatic bacteriuria due to the original Esch. coli $O$ type is detected. In both groups of patients we have sometimes found that the organism is absent from the faeces and this suggests that infection has persisted in the renal tract. Where the organism is absent from the urine and then reappears the question of whether there is a silent focus of infection in the kidney must be seriously considered.

It has been suggested that organisms may survive as spheroplasts in the hypertonic environment of renal medulla and by periodically reverting to bacilliary forms produce recurrent episodes of infection (Braude, Siemienski, and Jacobs, 1961; Alderman and Freedman, 1963). However, it is difficult to obtain direct evidence of foci of infection from patients with subacute or chronic pyelonephritis. Culture of 66 kidney biopsies which showed histological features suggestive of chronic pyelonephritis, supported either by characteristic radiological changes or subsequent post-mortem confirmation, were all sterile (Brumfitt, 1964). We have therefore made a different approach to the problem by looking for antibodies against the organism responsible for acute renal infection (Brumfitt and Percival, 1964). It has been found that patients with a lesion involving the renal tissues have significantly greater levels of antibody against the $O$ antigen of the organism responsible than those patients in whom infection is confined to the bladder. Where the renal lesion persists the antibody titre remains elevated but if the infection is then eliminated by chemotherapy the serum antibody gradually disappears.

Further evidence of persistent renal infection is available from animal experiments where acute infection was induced in both kidneys of the rat by temporary ureteric occlusion combined with intravenous injection of Esch. coli. The infection was allowed to heal for periods of six weeks and three months at which time the left ureter was completely occluded and the animals were killed 48 hours later. Organism counts of both kidneys showed that reactivation of the infection took place in a high proportion of rats at six weeks and in a smaller but significant number of rats at three months (Heptinstall and Brumfitt, 1960).

Recurrent infections Recurrent episodes of infection by different organisms can also cause progressive damage to renal tissue. Following eradication of infection from the urinary tract, as judged by examination of at least two mid-stream specimens of urine taken four days and six weeks after the end of treatment, recurrence of infection is most often due to an unrelated Esch. coli $\mathrm{O}$ serotype.

Episodes of re-infection may be associated with organic or functional abnormality in the renal tract which interferes with the flow of urine. For example, obstruction to the flow of urine at any point from the proximal tubule to the terminal urethra can increase susceptibility to infection in that part of the urinary system proximal to the obstruction. On the other hand, in those women in whom urinary tract infection follows sexual intercourse, no initial abnormality may be found but urethritis is followed by an ascending infection (see below).

The conclusion so far must be that susceptibility to infection resulting in re-infection by exogenous organisms as well as persistence of focal infection in the renal tissue are both important and, indeed, often complementary to each other in causing progressive renal destruction. There is no evidence that any pathological process apart from infection plays a part in the development of chronic pyelonephritis. If bacterial infection is implicit in the development of chronic pyelonephritis it is clearly pertinent to consider how infection of the kidney can be initiated.

ROUTES OF INFECTION Bacteria can reach the kidney by the ascending, haematogenous, or lymphatic routes or by direct spread from the adjacent colon. Of these four only the ascending and haematogenous routes merit further consideration.

Haematogenous infection The use of the haematogenous route for producing experimental pyelonephritis has given valuable information about the way in which the pyelonephritis lesion develops following the establishment of a renal infection. However, haematogenous infection with Esch. coli and most other urinary pathogens in the experimental animal can only be achieved when abnormal conditions in the urinary tract are present. For example, a common experimental procedure is ureteric ligation which not only obstructs the flow of urine but also reduces renal blood flow (Lucas, 1908; Idbohrn and Muren, 1956). Experimentally, it is unusual to be able to produce a renal infection even when very large numbers of Esch. coli are injected intravenously, and bacteriaemias with such organisms are rarely if ever found in people with 
normal urinary tracts. Similarly although haematogenous infection of the kidney may occur after instrumentation or operation on the urinary tract in the presence of infection it is unlikely that this route is common in the healthy individual with a normal urinary tract.

Ascending infection Infection of the urine is more common in women than in men, at least until the age of prostatic hypertrophy is reached when the incidence of urinary tract infection in males shows a sharp increase. One important reason for this difference is that the female urethra is only $4 \mathrm{~cm}$. in length compared with an average length of $20 \mathrm{~cm}$. in the male. Helmholz (1950) found that bacteria could be recovered from $49 \%$ of 72 normal male urethras at a depth of $5 \mathrm{~cm}$., both Gram-negative and Gram-positive bacteria being isolated. Bacteria, including Escherichia and Proteus species, are also present in the female urethra (Guze and Beeson, 1956; Clabaugh and Rhoads, 1957) and therefore if colonization occurred as in the male it is possible that bacteria would constantly enter the female bladder. However, direct suprapubic aspiration of bladder urine in 12 patients produced sterile urine (Guze and Beeson, 1956) and the bladder is inherently resistant to infection (Guyon, 1889; Rovsing, 1898; Cox and Hinman, 1961a and b). However, in ascending infection it is important to consider not only (1) host resistance but also (2) the ability of the infecting organism to initiate infection. These will be considered separately.

1 Local bladder defences (Cox and Hinman, 1961b) and inhibitory substances in the urine (Guze, 1961) may play a part in resistance to infection but at the present time little is known of their exact nature or importance. There is, however, no doubt that completely emptying the bladder at intervals is of primary importance in combating urinary tract infection. If bacteria gain access to the bladder urine the vast majority are washed away at micturition provided that the bladder is completely emptied (Fig. 1). Where the bladder is incompletely emptied (Fig. 2), once bacteria gain access to the bladder the residual urine containing bacteria provides an inoculum which leads to a gradual build-up of the bacterial population within the bladder. This situation may subsequently lead to tissue invasion and the development of a clinically apparent infection.

Structural or neuromuscular abnormalities which result in incomplete bladder emptying are known greatly to increase the risk of urinary infection and where the frequency of micturition is reduced the danger is further increased. However, it is likely that even minor degrees of temporary muscular dysfunction or incoordination, which lead to a residual urine of only a few millilitres, can be crucial in determining whether or not small numbers of bacteria in the bladder are able to initiate urinary infection.

Infection of the bladder wall is by no means always associated with spread of the infection to the upper urinary tract. This is because in the human, and in a number of animal species, the presence of a valve at the lower end of each ureter prevents urine from passing to the upper urinary tract when the intravesical pressure is raised during micturition. Obviously incompetence of this valve would allow access of infected urine to the upper urinary tract and this might lead to renal involvement (Fig. 3). Also, the urine contained in the upper urinary tract would again enter the bladder when micturition was completed and would tend to perpetuate bladder infection by causing a residual urine (Fig. 3).

It has been suggested that incompetence of the vesico-ureteric valve with reflux of urine is found in a

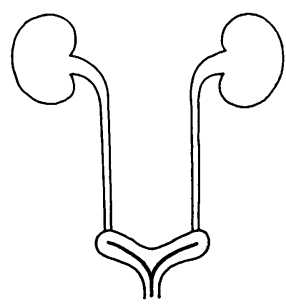

FIG. 1.

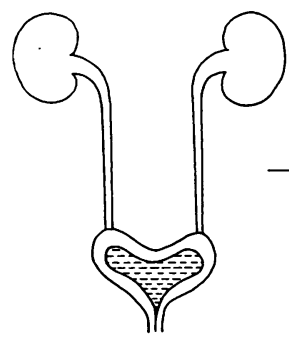

FIG. 2 .

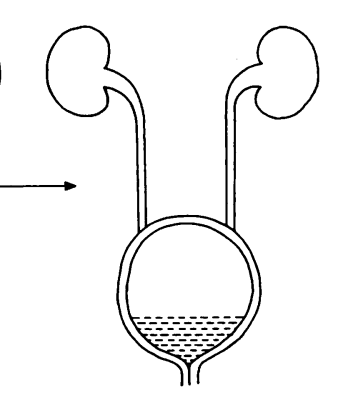

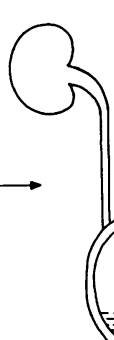

FIG. 3.

FIG. 1. Normal bladder action: the bladder at the end of micturition contains no residual urine.

FIG. 2. Abnormal bladder action: micturition completed but the bladder contains residual urine. If bacteria are already present in this urine they form an inoculum which perpetuates infection.

FIG. 3. Complete bladder emptying (as in Fig. 1) but note the reflux of urine on the right. When the bladder relaxes infected urine re-enters the bladder and allows persistence of infection (as in Fig. 2). If infected urine reaches the renal pelvis it may initiate an episode of acute pyelonephritis. 
substantial number of apparently normal individuals (Forsythe and Whelan, 1958) but this has been denied by most other workers (Campbell, 1951; Edwards, 1961 ; McGovern, Marshall, and Paquin, 1960). There is no doubt that many patients with chronic pyelonephritis have an incompetent vesicoureteric sphincter and once reflux is established the mechanical effect of back pressure is said to be associated with progressive destruction of renal tissue (Edwards, 1960), and, as already shown (Fig. 3), this lesion is liable to lead to persistent urinary tract infection with access of infected urine to the kidney on the affected side.

However, in many patients with chronic pyelonephritis, reflux cannot be demonstrated. We hold the view that infection and not reflux is the primary factor which results in spread of infection to the upper urinary tract. It has been demonstrated by the technique of micturating cystography that during acute episodes of cystitis some patients show reflux which resolves when the infection is controlled (Hanley, 1963). It has also been shown at necropsy that where acute cystitis is associated with renal infection reflux is present in approximately half the patients (Brumfitt and Percival, 1964). By contrast, if infection is confined to the bladder reflux cannot be elicited.

Our conclusion is that acute cystitis may produce inflammation and oedema round the ureteric orifice and this can lead to temporary reflux with spread of infection to the kidney. It is unnecessary to postulate primary incompetence of the vesicoureteric valve to explain ascending infection from the bladder to the upper urinary tract, although once established such a lesion increases the danger of renal involvement in a patient who is subject to recurrent lower urinary tract infection.

The final question is how bacteria reach the bladder and initiate the primary infection. We have evidence that in many patients infection of the bladder urine is preceded by a urethritis. The finding that infection is more common in women than in men and also more common in married than in single women suggests that a urethritis following sexual intercourse is responsible for the initiation of infection of the bladder urine. This probably occurs in two ways; first by increasing the number of bacteria entering the bladder and secondly because of the dysuria which accompanies urethritis the bladder may be incompletely emptied. Thus the two key factors of increased bacterial inoculum together with residual bladder urine allow infection to be established.

2 Most urinary infections are caused by Esch. coli and it has been shown that the majority of these strains belong to a few specific serological groups
(Kauffmann, 1947; Ujváry, 1958). This may suggest that not only do Esch. coli have a special ability to initiate urinary tract infection in the human but that there are particular strains which are more invasive for the urinary tract than others.

Kauffmann (1947) claimed that Esch. coli strains capable of causing severe urinary tract infection in the human often possessed the $\mathrm{K}$ antigen. Experimental studies in the rat do not support this claim, since a strain of Esch. coli which possessed no $\mathrm{K}$ antigen regularly produced more severe renal lesions than a strain of Esch. coli which carried the $\mathrm{K}$ antigen (Brumfitt and Heptinstall, 1960).

It has also been found that a limited number of O groups are commonly associated with urinary tract infection (Ujváry, 1958; Rantz, 1962; Turck and Petersdorf, 1962). Rantz (1962) further suggested that these $\mathrm{O}$ groups of Esch. coli were more invasive for the urinary tract than others but Turck and Petersdorf (1962) hold the view that infections by these organisms are common only because they are also prevalent in the environment.

In order to define the incidence of infection by these Esch. coli $\mathrm{O}$ serotypes we prepared antisera against $O$ groups $1,2,4,5,6,7,9,11,18,39$, and 75 . The results of our investigations in three groups of patients are shown in Table I. In the hospital patients nearly all had a history of recurrent urinary infections and the others became infected following instrumentation or operation on the urinary tract.

\section{TABLE I}

INCIDENCE OF ESCH. COLI. STRAINS AND O SEROTYPES IN DIFFERENT GROUPS OF PATIENTS WITH URINARY TRACT INFECTION

\begin{tabular}{|c|c|c|c|}
\hline & \multirow{2}{*}{$\begin{array}{l}\text { No. of Patients } \\
\text { with Urinary } \\
\text { Tract Infection }\end{array}$} & \multicolumn{2}{|c|}{ Incidence of Esch. coli } \\
\hline & & Total & $\begin{array}{l}\text { Groupable } \\
\text { Strains }\end{array}$ \\
\hline $\begin{array}{l}\text { Domiciliary patients } \\
\text { Bacteriuria of pregnancy } \\
\text { Hospital patients }\end{array}$ & $\begin{array}{r}43 \\
182 \\
120\end{array}$ & $\begin{array}{r}33(77 \%) \\
153(84 \%) \\
56(47 \%)\end{array}$ & $\begin{array}{l}26(79 \%) \\
70(45 \%) \\
31(55 \%)\end{array}$ \\
\hline Total & 345 & $242(70 \%)$ & $127(52 \%)$ \\
\hline
\end{tabular}

It can be seen in Table $I$ that the incidence of Esch. coli infections and the proportion which could be grouped were both significantly lower in these patients than in patients from domiciliary practice.

In women with bacteriuria of pregnancy the incidence of infection due to Esch. coli was similar to that found in domiciliary practice whilst the proportion of strains which could be grouped was similar to that seen in hospital patients. These findings in pregnant women (who were out-patients) raise the interesting possibility that they are more susceptible to infection than the other group of domiciliary patients studied. 
In a small group of 11 domiciliary patients a rectal swab was taken immediately before collection of the urinary specimen. In addition to grouping the Esch. coli from the urine the group of each of 10 colonies of Esch. coli grown from the rectal swab was also determined. In three patients the urinary strain was not found in the faecal material whilst in another four it was not numerically preponderant.

Our findings, therefore, support the observations of Rantz (1962) that certain O groups of Esch. coli are more pathogenic for the urinary tract. However, the particular properties of those strains which confer the ability to initiate urinary tract infection have not yet been defined.

\section{LABORATORY DIAGNOSIS}

SIGNIFICANT BACTERIURIA The diagnosis of acute infections of the urinary tract can be established by bacteriological examination of the urine provided that contamination by bacteria from the urethra and external genitalia is differentiated from true bacterial infection. This can be achieved in the great majority of specimens by carrying out quantitative bacterial counting (Marple, 1941; Kass, 1957). Figure 4 is a diagrammatic representation of the results of quantitative bacterial counts carried out on urine specimens from large numbers of hospital patients. It shows a bimodal distribution. In specimens obtained from patients with clinically obvious urinary tract infection, the counts were 100,000 or more bacteria per ml. of urine. In specimens obtained from patients with no history or evidence of urinary tract infection the counts were nearly always below 3,000 bacteria per $\mathrm{ml}$. of urine and there was usually a mixed growth of several different organisms in contrast to the pure growth of a single organism found in the majority of infected urines. In approximately $5 \%$ where the counts were between 3,000 and 100,000 per ml., examination of a second specimen resolved

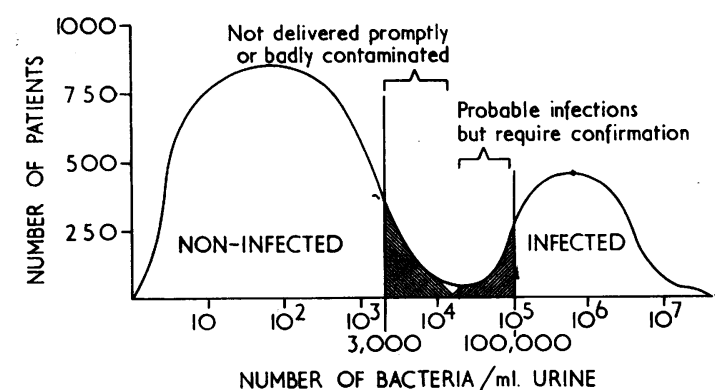

FIG. 4. Results of quantitative bacterial counting carried out on urine. the difficulty in interpretation. It is on the basis of such findings as these (Kass, 1956) that 100,000 or more bacteria per $\mathrm{ml}$. of urine has become theo accepted standard of a 'significant bacteriuria' and등 it is usually taken as indicating the presence of $\bar{c}$ actively multiplying bacteria in the bladder urine. $\mathbb{\Phi}$

Under certain circumstances counts may be below 100,000 per $\mathrm{ml}$. although acute bacterial ${ }_{-}^{\infty}$ infection is present. Examples are the presence of: inhibitory substances in the urine and marked $\overrightarrow{\vec{H}}$ frequency or the drinking of large volumes of fluido when urine is not present in the bladder long enougho for bacterial multiplication to have reached the figure of 100,000 per $\mathrm{ml}$. For the same reason, much. lower counts may be regarded as indicative of infection in ureteric or nephrostomy urine.

COLLECTION OF SPECIMENS It is important to avoid $\stackrel{?}{?}$ heavy vaginal contamination and to obtain satis- $C$ S factory specimens, but, because a single catheteriz- $-\frac{\mathbb{O}}{0}$ ation carries a 4 to $6 \%$ risk of introducing infection $\mathbb{\triangle}$ (Marple, 1941; Brumfitt, Davies, and Rosser, 1961)응 this procedure is not justified merely to obtain $\mathrm{a} \stackrel{\mathbb{}}{-}$ specimen for diagnostic purposes. Therefore, investi- $\vec{\theta}$ gations are carried out on carefully taken midstream specimens. In the Ante-natal Clinic ato Edgware General Hospital every new patient first? visits the almoner and is given a printed slip with instructions (available in several different languages) together with a wide-necked disposable plastic $\mathbb{\varnothing}$ container with lid (Metal Box Co.) and a small piece of plastic sponge moistened with hibitane and음 cetrimide. The patient collects a mid-stream specimen in the lavatory and hands it to the nurse who immediately places it in the refrigerator at $4^{\circ} \mathrm{C}$. to await transportation to the laboratory. Approxi- $\overline{8}$ mately $95 \%$ of specimens obtained in this way have proved satisfactory.

Instructions for collecting specimens of urine

1 With the specially prepared moistened sponge?

wipe the vulva from before backwards.
Replace the sponge in the foil container and을 drop both into the labelled bin (not into the N toilet).

2 Allow some urine to pass into the toilet, then? allow some to pass into the clean container $\omega$ provided.

3 Clip the lid on firmly.

ASYMPTOMATIC BACTERIURIA Screening trials ini- 0 tially carried out by Kass (1956) in America on ${ }_{0}^{\circ}$ urine specimens from large numbers of individuals $\vec{\Omega}$ in different hospital departments have demonstrated $\underset{\otimes}{\circ}$ a surprisingly high incidence of significant bacteri- 
uria in the complete absence of any symptoms referable to the urinary tract. Furthermore, a relationship between this condition of asymptomatic bacteriuria and pyelonephritis has been demonstrated in pregnancy, where Kass (1960) found that $40 \%$ of women who were found to have asymptomatic bacteriuria at their first visit to the ante-natal clinic developed pyelonephritis later in pregnancy.

These findings suggest a need for the general introduction of routine screening of the urine for the presence of significant bacteriuria, particularly in groups known to be associated with a high incidence of urinary tract infection, for example, those attending ante-natal, diabetic, and genitourinary clinics and perhaps patients in the medical out-patient department also. Such a programme would place a heavy load upon bacteriological laboratories. Therefore, in order to define the most reliable and economic screening test, studies have been carried out at Edgware General Hospital using different tests in parallel with quantitative counting.

METHODS OF ESTIMATING NUMBERS OF BACTERIA IN URINE The methods used are listed in Table II.

\section{TABLE II}

METHODS FOR ESTIMATING BACTERIA IN URINE

$\begin{array}{lll}1 & \text { Quantitative } & \begin{array}{l}\text { Surface viable counts } \\ \text { Pour plates } \\ \text { 'Standard' loop } \\ \text { Filter paper strips }\end{array} \\ 3 & \text { Semi-quantitative } & \begin{array}{l}\text { Screening tests } \\ \text { Chemical }\{\text { T.T.C. test } \\ \text { Nitrite test }\end{array} \\ & \text { W.B.C. }\end{array}$

The most reliable is direct quantitative counting carried out by making tenfold dilutions of the urine in broth or distilled water and either spreading $0.1 \mathrm{ml}$. on a MacConkey agar plate or incorporating $1 \mathrm{ml}$. in melted agar and then making pour plates. In practice only two dilutions, tenfold and one thousandfold, are needed to allow differentiation between contamination and true infection but even so this method when used in every case is obviously extravagant both of materials and of the technician's time.

Of the semi-quantitative methods, the first is very simple and consists merely of using a 2,3 , or $5 \mathrm{~mm}$. loopful of uncentrifuged urine to inoculate whole plates. There has been considerable variation in the reliability of this method when compared with quantitative counting according to the reports of different studies. Some (O'Sullivan, FitzGerald, Meynell, and Malins, 1960; McGeachie and Kennedy, 1963; Guttmann and Stokes, 1963) claimed close agreement between the two methods. On the other hand, Bradley and Little (1963) compared their results using quantitative counting with the routine laboratory reports based on the loop method and found that in many instances it was not possible to distinguish from the routine laboratory reports whether the urine was contaminated or infected. In our experience, the loop method is not the most satisfactory of the screening procedures. Although most urines could easily be classified as obviously infected or obviously not infected, there remained a group of approximately $15 \%$ in which we could not assess adequately the number of organisms present and had to check by quantitative counting. Only if great care is taken in plating out, the results read by an experienced bacteriologist, and quantitative counts carried out in the doubtful $15 \%$ is the loop method reasonably satisfactory. However, since such a small sample volume is used, a high degree of reliability would not be expected, particularly if only one plate is used for each urine.

Ryan, Hoody, and Luby (1962) described a technique for quantitative bacterial counts using filter paper strips. This quantitative method has been used in our laboratory to screen a large number of urine specimens for significant bacteriuria.

Strips of sterilized absorbent filter paper, $\frac{1}{4}$ in. wide, with a foot folded at an angle of approximately $45^{\circ}$ $\frac{1}{2}$ in. from one end, are used. The foot is quickly dipped in the urine, excess drained off by touching the side of the container and an impression of the foot made on welldried MacConkey agar. Each urine is done in duplicate side by side. The number of colonies in the impression area is proportional to the numbers of bacteria in the urine. With the filter paper ${ }^{1}$ used in our laboratory, 30 or more colonies correspond to 100,000 or more per ml. and no colonies to less than 1,000 per ml. Furthermore, in the critical range between 10,000 and 100,000 per ml., individual colonies can be counted, mixed growth recognized, and the bacterial count read off a standard curve. By this method, 50 urines can be put up in less than half an hour using no more than five MacConkey plates.

The triphenyl tetrazolium chloride (T.T.C.) test depends upon the ability of respiring bacteria to reduce the soluble colourless triphenyl tetrazolium chloride to a red insoluble form (Wundt, 1950), seen as a red precipitate. When $2 \mathrm{ml}$. of urine is incubated with $0.5 \mathrm{ml}$. of reagent for four hours at $37^{\circ} \mathrm{C}$. a positive result is given by urines containing 100,000 or more bacteria per $\mathrm{ml}$. (Simmons and Williams, 1962). Figure 5 shows a positive and a negative result. In reading this test, it is important to regard even a fine deposit of tiny red particles as

${ }^{1}$ Postlip, fibrefree, fluffless, Mill 633, Horwell and Co., 17 Cricklewood Broadway, London, N.W.2. 


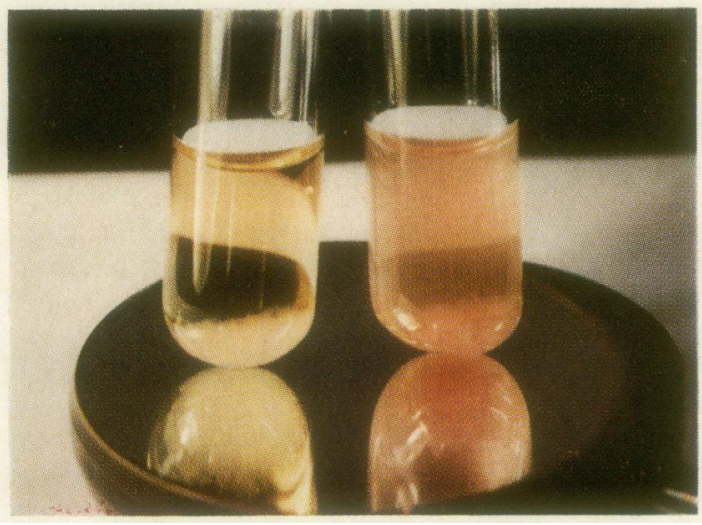

FIG. 5. Negative and positive T.T.C. tests. The presence of a red colour indicates a count exceeding 100,000 bacteria per millilitre.

positive and this can best be done with the aid of a concave mirror.

The other chemical screening test, the nitrite test of Griess, depends upon the ability of actively respiring bacteria to reduce any nitrate present in the urine to nitrite so that a red colour develops on the addition of a reagent containing sulphanilicacid, aceticacid, and alphanaphthylamine.

Table III shows the results of a comparison of the T.T.C. and nitrite tests with quantitative counting in 1,136 specimens from hospital patients (Williams and Simmons, 1963) and in 3,000 specimens from pregnant women at their first visit to the ante-natal clinic (Leigh and Williams, 1964). The T.T.C. test gave a $96 \%$ agreement with quantitative counting in urines with 100,000 or more bacteria per ml. and only $2 \%$ false positives. The nitrite test was carried out by adding excess nitrate to the urine as substrate and then incubating at $37^{\circ} \mathrm{C}$. for one hour before adding the colour reagent but even so only gave a $61 \%$ correlation with quantitative counting. The T.T.C. test was less satisfactory in detecting

\section{TABLE III}

COMPARISON OF T.T.C. AND NITRITE TESTS WITH QUANTITATIVE COUNTING

\begin{tabular}{|c|c|c|c|c|c|}
\hline \multirow[t]{2}{*}{ Type of Patient } & \multirow{2}{*}{$\begin{array}{l}\text { No. of } \\
\text { Urines } \\
\text { Tested }\end{array}$} & \multicolumn{2}{|c|}{$\begin{array}{l}\text { T.T.C. }{ }_{\text {Above }}{ }^{\text {Below }} \\
\end{array}$} & $\begin{array}{l}\text { Nitrite }+ \\
\text { Above }\end{array}$ & Below \\
\hline & & $10^{5}$ & $10^{5}$ & $10^{5}$ & $10^{5}$ \\
\hline $\begin{array}{l}\text { Hospital } \\
\text { Ante-natal }\end{array}$ & $\begin{array}{l}1,136 \\
3,000\end{array}$ & $\begin{array}{l}96 \% \\
78 \%\end{array}$ & $\begin{array}{l}2 \% \\
0.7 \%\end{array}$ & $61 \%$ & $1 \%$ \\
\hline
\end{tabular}

asymptomatic bacteriuria of pregnancy, there being an overall correspondence of only $78 \%$ with quantitative counting, $87 \%$ of infections due to Gram-negative organisms being positive as opposed to only $22 \%$ of those due to Gram-positive organisms.

Table IV shows the results of a comparison of the T.T.C. test and the filter paper strip technique with흘 quantitative counting carried out on specimens from a further group of 1,203 women in the ante- $\frac{\Phi}{2}$ natal clinic (Leigh and Williams, 1964). This showses the filter paper method to be more reliable than theT.T.C. test in bacteriuria of pregnancy.

\section{TABLE IV}

COMPARISON OF FILTER PAPER TECHNIQUE AND T.T.C. TESTS WITH QUANTITATIVE COUNTING IN BACTERIURIA OF PREGNANCY

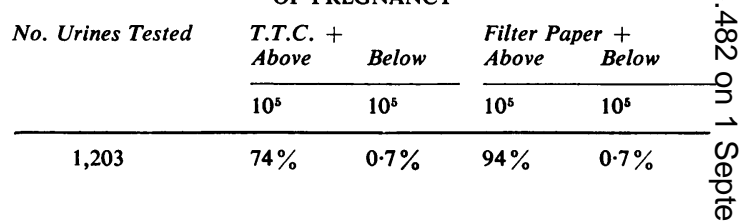

DETERMINATION OF INCREASED URINARY WHITE CELL胥 EXCRETION The only satisfactory way to detecton small increases in urinary white cell excretion is by $\vec{c}$ collecting a timed (2-4 hr.) sample, measuring theos total volume, counting the white cells in the pooled ${ }^{f}$ specimen, and calculating the rate of white celb excretion per hour. Counting the white cells in uncentrifuged urine using a haematological countingo chamber is less accurate but more reliable than theo commonly employed practice of examining a drop $\mathbb{Q}$ of a centrifuged deposit under the high power $\overrightarrow{\overrightarrow{0}}$ because in the latter case there are too many variable 3 factors involved.

Although the practice of putting up directo sensitivity tests on urines with an excess of white cells is a useful means of providing a rapid service to the clinicians, the procedure of culturing onlys those urines with an excess of white cells must be condemned. Table $\mathrm{V}$ shows the number of white cells per cubic millimetre of urine in three groups of patients with urinary tract infection. In the first group of 283 patients with symptoms studied (Brumfitt, and Percival 1962; Brumfitt, Percival, ande. Carter, 1962), 93\% had more than 50 per c.mm N

\section{TABLE V}

W.B.C. COUNTS IN URINE OF PATIENTS WITH SIGNIFICANT BACTERIURIA

\begin{tabular}{lrlccc} 
Type of Patient & $\begin{array}{c}\text { No. } \\
\text { Studied }\end{array}$ & $\begin{array}{l}\text { W.B.C. per c.mm. } \\
\text { Above }\end{array}$ & & Below \\
\cline { 2 - 3 } \cline { 5 - 6 } & 50 & $10-50$ & 10 \\
\hline $\begin{array}{c}\text { Symptomatic } \\
\begin{array}{c}\text { Symptomatic } \\
\text { (domiciliary) }\end{array}\end{array}$ & 283 & $93 \%$ & $96 \%$ & $4 \%$ & 0 \\
$\begin{array}{c}\text { Bacteriuria of } \\
\text { pregnancy }\end{array}$ & 163 & $25 \%$ & $32 \%$ & $43 \%$ &
\end{tabular}


This is an obvious excess, corresponding approximately to more than 5 per high-power field. Subsequently it has been shown (Little, 1964) that when urines contained more than 10 white cells per c.mm., the excretion rate was always above 400,000 per hour which is considered to be abnormally high (Little, 1962). Counts of below 3 per c.mm. were always associated with an excretion rate of below 400,000 per hour. Taking 10 white cells per c.mm. as a definite indication of increased urinary white cell excretion, we found that in every case of a group of 43 patients with symptoms from a single domiciliary practice, the counts were above this figure. In contrast, in 163 women with bacteriuria of pregnancy only $25 \%$ had an obvious excess of white cells, $32 \%$ a slight excess which might have been missed using microscopy of the centrifuged deposit, and in $43 \%$ there was no definite excess. Furthermore, in $25 \%$ the counts were below 3 per c.mm. indicating a normal white cell excretion rate. A screening programme of ante-natal cases in which only urines with an excess of white cells (as judged by examination of the centrifuged deposit) werecultured would therefore be likely to miss approximately half of those with significant bacteriuria.

DIAGNOSIS OF PYELONEPHRITIS The presence of infection of the renal tissues is clearly indicated in patients with the classical clinical features of acute pyelonephritis: dysuria, frequency, loin pain, high fever, rigors, and loin tenderness. That active pyelonephritis may be present in patients with symptoms confined to the lower urinary tract, or even in the absence of symptoms referable to the urinary tract, has been repeatedly emphasized (Thomson-Walker, 1926; Gibson, 1928; Rantz, 1942) and has been clearly demonstrated in postmortem studies (Longcope and Winkenwerder, 1933; Kleeman, Hewitt, and Guze, 1960). On the other hand, post-mortem studies have also shown that in many patients with significant bacteriuria the infection is limited to the lower urinary tract (MacDonald, Levitin. Mallory, and Kass, 1957). Furthermore, in the living patient, the finding of sterile ureteric urine despite the presence of significant numbers of bacteria in the bladder urine is not uncommon in our experience and has been reported by others (Albeck, 1907. McLane and Traut, 1937; Monzon, Armstrong, Pion, Deigh, and Hewitt, 1963).

Therefore, it is of fundamental importance to be able to determine in the individual patient with significant bacteriuria whether renal infection is present or not. Unfortunately, a practicable test which would allow differentiation between infection confined to the lower urinary tract and that also involving the renal tissue has yet to be established. We have approached this problem by measuring the $\mathrm{O}$ antibody response of patients with pyelonephritis and those in whom infection was confined to the lower urinary tract (Brumfitt and Percival, 1964). We have found a quantitative difference between the $\mathrm{O}$ antibody levels (measured by bacterial agglutination) in the two types of infection. Moreover, rising titres which were specific for the $O$ group of the infecting strain of Escherichia coli could regularly be demonstrated in the patients with pyelonephritis. When this method of investigation was applied to women with bacteriuria of pregnancy, approximately one third were found to have high titres suggestive of renal tissue infection and this often occurred early in pregnancy in women who were still in the asymptomatic phase. Estimation of the antibody response appears to provide a valuable indication of the presence of pyelonephritis and may prove to be a useful means of studying the natural history of the disease.

PROVOCATION TESTS IN CHRONIC PYELONEPHRITIS Diagnosis of chronic pyelonephritis is even more difficult since the urine is frequently sterile and there may be no history of previous urinary tract infection. However, the lipopolysaccharide or prednisolone provocation tests are of some value in suggesting a diagnosis of chronic pyelonephritis in a proportion of patients with this disease.

Pears and Houghton (1959) found that patients with chronic pyelonephritis showed an increase in the urinary white cell excretion rate after the injection of lipopolysaccharide. Normal individuals and those with other chronic renal diseases did not respond in this way. This study was repeated and extended by others (Hutt, Chalmers, MacDonald, and De Wardener, 1961 ; Leather, Wills, and Gault, 1963) who obtained positive results in only approximately half the patients with definite evidence of chronic pyelonephritis. However, the test was not specific for chronic pyelonephritis since a smaller proportion of patients with glomerulonephritis also showed a positive response. In both studies prior treatment with antibiotics was shown to reduce the incidence of positive results. Subsequently, it was found that injection of prednisolone phosphate gave a somewhat higher incidence of positive tests than lipopolysaccharide when carried out sequentially in the same group of patients (Little and De Wardener, 1962). The use of prednisolone had the important advantage of not causing the unpleasant side-effects which follow injection of lipopolysaccharide.

We have used the prednisolone stimulation test both as a diagnostic aid in patients with chronic pyelonephritis and as a means of assessing the 
response to antibiotic treatment in patients following attacks of acute pyelonephritis. In carrying out the test, we merely collect two four-hour urine samples one before and the other after the intravenous injection of $40 \mathrm{mg}$. prednisolone phosphate and examine the urine for bacteriuria 24 hours later. In 32 patients with chronic pyelonephritis, the test was positive in $13(40 \%)$ but we also obtained positive results in two patients subsequently shown at necropsy to have glomerulonephritis. In 26 patients in whom there was clinical and bacteriological cure after antibiotic treatment for episodes of acute pyelonephritis the test was positive in eight $(30 \%)$. The significance of a positive prednisolone stimulation test following apparently successful antibiotic treatment was not evident, since none of these eight patients showed a subsequent relapse of infection due to the same organism and at least four have remained free of infection for one to two years.

None of the reports mentioned above contain any evidence as to the underlying mechanisms responsible for the increased white cell excretion obtained in some patients with chronic pyelonephritis. We have only once observed the appearance of a significant bacteriuria following the prednisolone provocation test. It is, therefore, unlikely that the increased white cell excretion rate is due to recrudescence of infection by living organisms present in the renal tissues. Another possibility is that the response to lipopolysaccharide may be a manifestation of a localized form of a Schwartzman reaction due to the persistence of bacterial antigen in the renal tissues. There is evidence from experimental pyelonephritis in the animal that antigen may persist in the renal parenchyma for an appreciable period after the disappearance of viable organisms (Sanford, Hunter, and Donaldson, 1962) and the $O$ somatic antigen is contained in the lipopolysaccharide fraction of the Gram-negative cell wall. An alternative explanation is that administration of corticosteroid may have the effect of lowering the host's ability to neutralize any lipopolysaccharide in the process of absorption from the renal tissues and it has been shown that lipopolysaccharide (endotoxin) injection itself leads to an increase in the level of circulating corticosteroids (Melby, Egdahl, and Spink, 1960). Whatever the explanation, the prognostic significance of the persistence of a positive provocation test following apparently successful antibiotic treatment of acute pyelonephritis in terms of a progressive renal lesion would only be revealed by long-term studies. The possible value of provocation tests in differentiating between pyelonephritis and infection confined to the lower urinary tract in patients with bacteriuria has not been evaluated.

\section{REFERENCES}

Albeck, V. (1907). Z. Geburtsh. Gynäk., 60, 466.

Alderman, M. H., and Freedman, L. R. (1963). Yale J. Biol. Med. $36,157$.

Box, C. R. (1908). Lancet, 1, 77.

Bradley, J. M., and Little, P. J. (1963). Brit. med., J. 2, 361.

Braude, A. I., Siemienski, J., and Jacobs, I. (1961). Trans. Ass. Ame Phycns, 74, 234.

Brod, J. (1956). Lancet, 1, 973.

Brumfitt, W. (1964). Unpublished.

$\longrightarrow$, Davies, B. I., and Rosser, E. ap. I. (1961). Lancet, 2, 1059. and Heptinstall, R. H. (1960). Brit. J. exp. Path., 41, 552. and Percival A. (1962). Lancet., 1, 186. (1964). Proceedings of 2 nd International Congress o Nephrology p. 106.

$\overline{\text { Campbell, }}, \frac{}{\text {, and Carter, M. J. (1962). Lancet., 1, } 130 .}$ (1951). Clinical Pediatric Urology. Saunders Philadelphia.

Clabaugh, F. G., and Rhoads, P. S. (1957). J. Amer. med. Ass., 165, 81 s,

Cox, C. E., and Hinman, F. Jr. (1961a). J. Urol., 86, 739.

- , (1961b). J. Amer. med. ass., 178, 919.

Edwards, D. (1960). In Recent Advances in Renal Disease, edited by M. D. Milne, p. 145, Pitman, London.

- (1961). Proc, roy. Soc. Med., 54, 1096.

Forsythe, W. I., and Whelan, R. F. (1958). Brit. J. Urol., 30, 189.

Gibson, A. G. (1928). Lancet, 2, 903.

Guttmann, D., and Stokes, E. J. (1963) Brit. med. J., 1, 1384.

Guyon, F. (1889). Ann. Mal. Org. gén.-urin., 7, 257.

Guze, L. B., (1961). Bull. N.Y. Acad Med., 37, 468.

, and Beeson, P. B. (1956). New Engl. J. Med., 255, 474.

Hanley, H. G. (1963). Lancet, 1, 22.

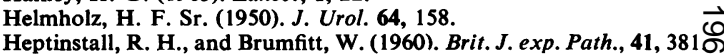

$\longrightarrow$, Michaels, L., and Brumfitt, W. (1960). J. Path. Bact., 80, 249. $₫$

Hutt, M. S. R., Chalmers, J. A., MacDonald, J. S., and De Wardener H. E. (1961). Lancet, 1, 351.

Idbohrn, H., and Muren, A. (1956). Acta physiol. scand., 38, 200.

Jackson, G. G., Dallenbach, F. D., and Kipnis, G. P. (1955). Med Clin. N. Amer., 39, 297.

Kalmanson, G. M., and Guze, L. B. (1962). Clin. Res., 10, 94.

- - (1963). Amer. J. med. Sci., 246, 532.

Kass, E. H. (1956). Trans. Ass. Amer. Physcns, 69, 56.

- (1957). Arch. intern. Med., 100, 709. (1960). Ibid., 105, 194.

Kauffmann, F. (1947). J. Immunol., 57, 71.

Kimmelstiel, P. (1960). In Biology of Pyelonephritis, edited by E. L Quinn and E. H. Kass, p. 269. Churchill, London.

—, Kim, O. J., Beres, J. A., and Wellmann, K. (1961). Amer. Med., 30, 589.

Kincaid-Smith, P. (1955). Lancet, 2, 1263.

Kleeman, C. R., Hewitt, W. L., and Guze, L. B. (1960). Medicine (Baltimore), 39, 3.

Kramer, N. C., Watt, M. F., Howe, J. H., and Parrish, A. E' (1961). Amer. J. Med., 30, 39.

Leather, H. M., Wills, M. R., and Gault, H. M. (1963). Brit. med. J., $1,92$.

Leigh, D. A., and Williams, J. D. (1964). J. clin. Path., this issue.

Little, P. J. (1962). Lancet, 1, 1149.

- (1964). Brit. J. Urol., in the press.

- and de Wardener, H. E. (1962). Lancet, 1, 1145. Hopk. Hosp., 53, 255 .
. T. T. (1933). Bull. Johns

Lucas, D. R. (1908). Amer. J. Physiol., 22, 245.

Macaulay, D., and Sutton, R. N. P. (1957). Lancet, 2, 1318.

MacDonald, R. A., Levitin, H., Mallory, G. K., and Kass, E. H (1957). New Engl. J. Med., 256, 915.

McGeachie, J., and Kennedy, A. C. (1963). J. clin. Path., 16, 32.

Mackay, I. R., and Larkin, L. (1958). Aust. Ann. Med., 7, 251.

McLane, C. M., and Traut, H. F. (1937). Amer. J. Obstet. Gynec. 33, 828.

Marple. C. D. (1941). Ann. intern. Med. 14, 2220.

McGovern, J. H., Marshall, V. F., and Paquin, A. J. Jr. (1960). J.T Urol., 83, 122.

Melby, J. C., Egdahl, R. H., and Spink, W. W. (1960). J. Lab. clin $\frac{\mathrm{O}}{\mathrm{D}}$ Med., 56, 50.

Monzon, O. T., Armstrong, D., Pion, R. J., Deigh, R , and Hewitt, W. L. (1963). Amer. J. Obstet. Gynec., 85, 511.

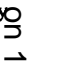


O’Sullivan, D. J., FitzGerald, M. G., Meynell, M. J., and Malins, J. M. (1960). J. clin. Path., 13, 527.

Pears, M. A., and Houghton, B. J. (1959). Lancet, 2, 1167.

Rantz, L. A. (1942). Advanc. intern. Med., 1, 137.

(1962). Arch. intern. Med., 109, 37.

Rovsing. T. (1898). Msber. Krankh. Harn. u. Sex App., 3, 506.

Ryan, W. L., Hoody, S., and Luby, R. (1962). J. Urol., 88, 838.

Sanford, J. P., Hunter, B. W., and Donaldson, P. (1962). J. exp. Med., 116,285

Simmons, N. A.: and Williams, J. D. (1962). Lancet, 1, 1377.
Simonsen, M., Buemann, J., Gammeltoft, A., Jensen, F., and Jørgensen, K. (1953). Acta path. microbiol. scand., 32, 1.

Thomson-Walker, J. (1926). Postgrad. med. J., 1, 41.

Turck, M., and Petersdorf, R. G., (1962). J. clin. Invest., 41, 1760.

Ujváry, G. (1958). Zbl. Bakt., I. Abt. Orig., 170, 394.

Williams, J. D., and Simmons, N. A. (1963). Lancet, 1, 1373.

Woodruff, J. D., and Everett, H. S. (1954). Amer. J. Obstet. Gynec., 68, 798.

Wundt, W. (1950). Dtsch. med. Wschr., 75, 1471. 